\title{
30. INTERSTITIAL WATER CHEMISTRY OF GAS-HYDRATE-BEARING SECTIONS ON THE MIDDLE AMERICA TRENCH SLOPE, DEEP-SEA DRILLING PROJECT LEG 84 ${ }^{1}$
}

\author{
Reinhard Hesse, Department of Geological Sciences, McGill University \\ Jean Lebel, Département d'Océanographie, Université du Québec à Rimouski \\ and \\ Joris M. Gieskes, Scripps Institution of Oceanography²
}

\begin{abstract}
On DSDP Leg 84, drilling was conducted at three gas-hydrate-bearing sites on the Middle America Trench slope off Costa Rica (Site 565) and off Guatemala (Sites 568 and 570). At Site 569, on the mid-slope off Guatemala, hydrates may be present, according to the seismic profile (GUA-13), although the pore-water composition does not provide clear evidence. Sites 566 and 567, on the lower Guatemala Trench slope, appear to be free of hydrates, except in fractures of serpentinite at the bottom of Hole 566.

Hydrate-bearing Sites 565,568 , and 570 show the effects of hydrate decomposition on pore-water chemistry that have been established during previous drilling at Sites 496 and 497 on the Guatemala Trench slope. These include a chlorinity decrease and $\delta^{18} \mathrm{O}$ increase downsection. The new results, however, reveal more complex relationships between the chlorinity decrease and $\delta^{18} \mathrm{O}$ increase than previously recognized. At Site $565, \delta^{18} \mathrm{O}$ values decrease in the middle section of the hole, whereas chlorinity continues to decrease from the top to near the bottom of the hole. Early diagenetic alteration of volcanic glass is suggested as a mechanism for the unexpected minimum in the O-isotope curve. Multiple fractionation by the pore-water/hydrate system is required to explain $\delta^{18} \mathrm{O}$-values greater than $2.7 \%$ at the bottom of Hole 568 , because with a fractionation factor of $\alpha=1.0027$, this is the maximum figure a single-stage fractionation could produce.

In situ water samples from hydrate zones in most cases failed to display the elevated salinities expected for the residual pore waters not involved in hydrate formation. This is probably because the in situ sampling device still allows a systematic pressure drop sufficient to trigger hydrate decomposition in the immediate vicinity of the sample port.
\end{abstract}

\section{INTRODUCTION}

During deep-sea drilling in 1979 on the Middle America Trench slope off Mexico (Leg 66, Shipley and Didyk, 1982) and off Guatemala (Leg 67, Harrison and Curiale, 1982), samples of submarine gas hydrates were recovered. The occurrence of hydrate zones seriously interfered with the objective of the Middle America active-margin cruises to test alternative tectonic models for trench slope evolution, and led to a return of the Glomar Challenger to the Guatemalan margin in 1982 (Leg 84). Drilling was carried out at five more sites (566-570), ranging in water depth from 1718 to $5529 \mathrm{~m}$ (Fig. 1), making the Guatemala transect the most intensely studied active margin of the Deep Sea Drilling Project. In addition, one hole (565) was drilled on the lower slope off Costa Rica during Leg 84.

Strong anomalies in pore-water chemistry detected during Leg 67 were explained by the hydrate-decomposition hypothesis (Hesse and Harrison, 1981; Harrison et al. 1982). According to this hypothesis, gas hydrates, upon decomposing, release isotopically heavy, fresh water to the pore fluids. In the process of core recovery, interstitial fluids will mix with this hydrate water, causing a de-

\footnotetext{
${ }^{1}$ von Huene, R., Aubouin, J., et al., Init. Repts. DSDP, 84: Washington (U.S. Govt. Printing Office).

2 Addresses: (Hesse) Department of Geological Sciences, McGill University, 3450 University Street, Montreal, Quebec H3A 2A7, Canada; (Lebel) Département d'Océanographie, Université du Québec à Rimouski, 300, avenue des Ursulines, Rimouski, Quebec GSL 3A1, Canada; (Gieskes) Scripps Institution of Oceanography, La Jolla, CA 92093.
}

crease in chlorinity and an increase in O-isotopic deltavalues. Findings of subsequent studies by Jenden and Gieskes (1983) and Gieskes et al. (this volume) support this hypothesis. Jenden and Gieskes also show that $\mathrm{H}$ isotopic data follow the same trend as that observed for $\mathrm{O}$-isotopic data.

Resampling of the hydrate zones on the Guatemala transect by the interstitial water program set up for Leg 84 thus provided a welcome opportunity to test some of the earlier results, particularly since on this leg an in situ pore-water sampler was successfully deployed. Pore-water samples were obtained at all six Leg 84 drill sites, and the results are presented in this chapter. Only the results for those sites for which sufficiently large numbers of samples were available (i.e., Sites 565, 568, 569, and 570), are discussed, however. Hydrate research became a focal point of the activities of Leg 84 (see Kvenvolden and McDonald, this volume) and was crowned with success when at Site 570 a solid 1-m core of pure hydrate (Plate 1) was recovered from a massive 4-m hydrate interval whose extent and physical properties were established by Schlumberger well logging (fig. 9 of Kvenvolden and McDonald, this volume).

\section{LABORATORY METHODS}

Pore waters were squeezed on board ship, following standard procedures (Manheim and Sayles, 1974), or collected with an in situ sampler in the drill hole (Barnes et al., 1979; Moore and Gieskes, 1980). Measurements of $\mathrm{pH}$ and salinity and determinations of chlorinity, $\mathrm{Ca}^{2+}$, and $\mathrm{Mg}^{2+}$ concentrations were done on board; the remaining ions were analyzed at the laboratory of the Université du Québec à Rimouski, following the methods of Gieskes (1974), Gieskes and Law- 


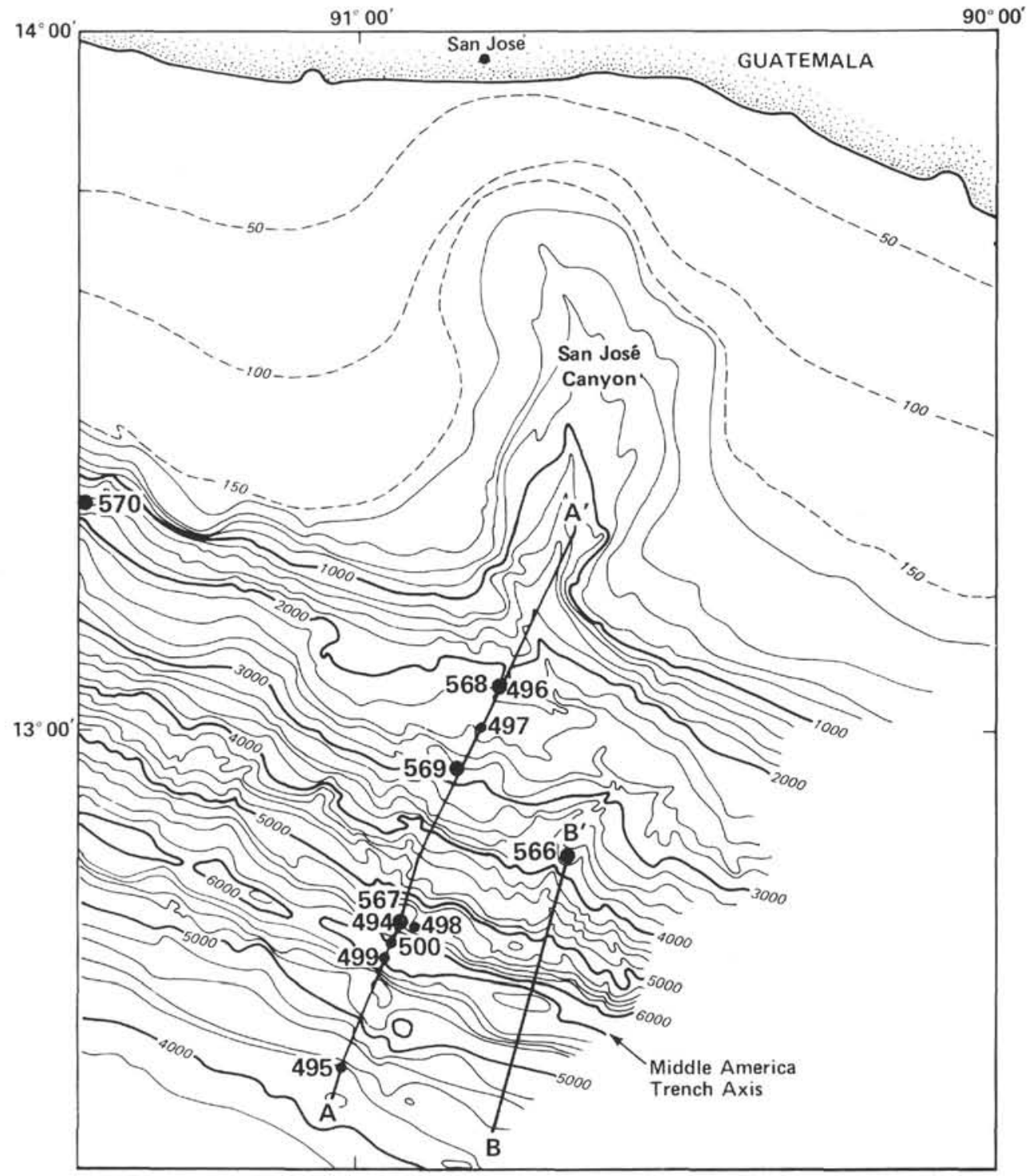

Figure 1. Map showing positions of drill sites on the Middle America Trench slope off Guatemala. Depth contours in meters. (Note: Site 565 on the trench slope off Costa Rica is not shown.)

rence (1976), and Presley and Claypool (1971, for sulfate). Oxygenisotope analyses were performed in Montreal at the facilities of the Université du Québec à Montreal, using the standard $\mathrm{CO}_{2}$-equilibration method (Epstein and Mayeda, 1953).

\section{RESULTS}

Analytical data for interstitial-water chemistry are tabulated in Table 1 and plotted on Figure 2.

\section{Site 565: Middle America Slope Off Costa Rica}

This site is on the Pacific slope off the Nicoya Peninsula, in $3111 \mathrm{~m}$ of water; Hole 565 was drilled to a subbottom depth of $328 \mathrm{~m}$ in dark, olive-gray mud and mudstone with rare interbeds of ash and sandstone. The site is $28 \mathrm{~km}$ landward from the trench axis. Shipboard scientists (site chapter, this volume) recognized the presence of gas hydrates, but were not able to identify their precise mode of occurrence-that is, whether they are dispersed in small concentrations throughout the mudstone or are restricted to more porous rocks and voids in fractures from which chips of hydrate were recovered (Kvenvolden and McDonald, this volume).

\section{Interstitial Water Chemistry}

Downhole variations of the various chemical properties and ions analyzed show the same general trends as those observed in gas-hydrate-bearing sections from Holes 496 and 497 of Leg 67, but the patterns are not as smooth. Salinity and chlorinity decrease downsection from Sal. $=35 \mathrm{~g} / \mathrm{kg}$ and $\mathrm{C}^{-}=19 \mathrm{~g} / \mathrm{kg}$ to Sal. $=24 \mathrm{~g} / \mathrm{kg}$ and $\mathrm{C} \ell^{-}=13 \mathrm{~g} / \mathrm{kg}$. There are local reversals in this trend, however, at $90 \mathrm{~m}$ sub-bottom (Core 565-10) and between 210 (Core 565-23) and $271 \mathrm{~m}$ sub-bottom (Core $565-29)$. Since these reversals are also evident in the curves for $\mathrm{Mg}^{2+}, \mathrm{SO}_{4}{ }^{2-}$, and perhaps for $\mathrm{Ca}^{2+}$, admixture of seawater from the drill hole in Cores 565-25 and $565-27$ cannot be excluded. This also agrees with a $\delta^{18} \mathrm{O}$ value close to 0 at $250 \mathrm{~m}$ and a local chlorinity maximum. 
Table 1. Interstitial water data, Leg 84.

\begin{tabular}{|c|c|c|c|c|c|c|c|c|c|}
\hline $\begin{array}{l}\text { Core- } \\
\text { section }\end{array}$ & $\begin{array}{l}\text { Sample } \\
\text { interval } \\
(\mathrm{cm})\end{array}$ & $\begin{array}{l}\text { Sub-bottom } \\
\text { depth } \\
\text { (m) }\end{array}$ & $\underset{(\mathrm{g} / \mathrm{kg})}{\mathrm{Sal}}$ & $\mathrm{pH}$ & $\underset{(\mathrm{g} / \mathrm{kg})}{\mathrm{Cl}^{-}}$ & $\begin{array}{c}\text { Alk, } \\
\text { (meq. } / \mathrm{kg} \text { ) }\end{array}$ & $\begin{array}{c}\mathrm{SO}_{4}^{2-} \\
(\mathrm{mM})\end{array}$ & $\begin{array}{c}\mathrm{H}_{4} \mathrm{SiO}_{4} \\
(\mathrm{mM})\end{array}$ & $\begin{array}{l}\mathrm{NH}_{3} \\
(\mathrm{mM})\end{array}$ \\
\hline Site 565 & & & & & & & & & \\
\hline s.w. & & 0.0 & & 7.63 & & 2.5 & & & \\
\hline 1S-1 & & 52.0 & 30.2 & & 16.8 & & 1.7 & 0.577 & 2.15 \\
\hline IS-2 & & 97.9 & 27.4 & & 14.6 & & 1.5 & 0.711 & 3.05 \\
\hline IS-3 & & 144.0 & 25.3 & & 13.5 & & 1.0 & 0.708 & 2.63 \\
\hline 1.5 & $139-145$ & 7.4 & 35.2 & 7.78 & 19.0 & 4.5 & 26.4 & 0.602 & 0.26 \\
\hline $2-5$ & $139-145$ & 17.9 & 34.2 & 7.80 & 18.8 & 11.2 & 17.8 & 0.668 & 1.13 \\
\hline 3-5 & $139-145$ & 27.4 & 32,7 & 7,80 & 18.5 & 19.0 & 6.0 & 0.734 & 1.62 \\
\hline $5-5$ & $139-145$ & 46.4 & 30.8 & 7.90 & 17.3 & 29.6 & 3.4 & 0.553 & 2.77 \\
\hline $6-4$ & $138-145$ & 54.4 & 30.8 & 7.95 & 17.0 & 28.0 & 7.2 & 0.510 & 3.05 \\
\hline $7-1$ & $138-145$ & 59.4 & 29.6 & 8.00 & 16.4 & 36.6 & 2.8 & 0.568 & 3.76 \\
\hline $8-4$ & $135-145$ & 73.4 & 29.4 & 7.80 & 15.8 & 38.5 & 2.9 & 0.701 & 3.78 \\
\hline 9.1 & $135-145$ & 78.4 & 29.2 & 8.20 & 15.8 & 37.0 & 4.3 & 0.488 & 4.56 \\
\hline 10-5 & $135-145$ & 93.9 & 31.9 & 7.90 & 15.3 & 36.0 & 4.1 & 0.648 & 3.36 \\
\hline $11-1$ & $135-145$ & 97.4 & 27.4 & 7.95 & 15.0 & 34.6 & 3.3 & 0.565 & 4.67 \\
\hline $13-5$ & $135-145$ & 122.4 & 26.2 & 8.18 & 14.4 & 37.0 & 3.2 & 0.538 & 5.27 \\
\hline $15-5$ & $135-145$ & 141.4 & 25,9 & 7.75 & 14.8 & 28.0 & 4.9 & 0.675 & 5.17 \\
\hline $17-1$ & $135-145$ & 154.4 & 27.4 & 7.88 & 14.2 & 28.0 & 4.0 & 0.724 & 3.99 \\
\hline 19.3 & $135-145$ & 176.4 & 25.4 & 7.90 & 14.0 & 23.4 & 4.1 & 0.670 & 5.19 \\
\hline $21-3$ & $135-145$ & 195.4 & 25.0 & 7.92 & 14.1 & 18.5 & 5.5 & 0.580 & 5.23 \\
\hline $23-1$ & $135-145$ & 211.4 & 24.2 & 8.22 & 13.6 & 15.0 & 4.0 & 0.277 & 5.82 \\
\hline 25.4 & $135-145$ & 234.9 & 26.4 & & 14.8 & & 8.8 & 0.483 & 5.97 \\
\hline 27.5 & $130-140$ & 255.4 & 27.6 & 7.75 & 15.4 & 9.4 & 12.2 & 0.605 & 6.64 \\
\hline 29.6 & $135-145$ & 275.9 & 24.2 & 8.10 & 13.9 & 10.5 & 4.1 & 0.260 & 7.05 \\
\hline Site 566 & & & & & & & & & \\
\hline s.w. & & 0 & 33.1 & 8.21 & 18.40 & 2.26 & & & \\
\hline 1.2 & $135-145$ & 2.9 & 33.2 & 7.43 & 19.14 & 4.59 & 19.9 & 0.719 & 0.48 \\
\hline $2-3$ & $140-150$ & 8.5 & 32.0 & 7.57 & 18.97 & 9.81 & 1.6 & 0.719 & 2.30 \\
\hline $4-2$ & $140-150$ & 15.3 & 32.7 & 7.65 & 18.97 & 11.64 & 8.0 & 0.725 & 2.46 \\
\hline Hole $567 \mathrm{~A}$ & & & & & & & & & \\
\hline 1.4 & $120-130$ & 201.3 & 33.0 & 7.54 & 19.07 & 11.94 & 6.0 & 0.746 & 5.75 \\
\hline 3.5 & $140-150$ & 222.4 & 30.0 & 7.55 & 19.14 & 7.17 & 6.8 & 0.613 & 5.03 \\
\hline $5-4$ & $140-150$ & 240.1 & 34.2 & 7.23 & 19.48 & 3.80 & 3.8 & 0.723 & 4.44 \\
\hline $8-2$ & $140-150$ & 265.7 & 33.6 & 7,18 & 19.54 & 2.32 & 6.2 & 0.715 & 3.89 \\
\hline $12-4$ & $140-150$ & 304.4 & 33.0 & 7.48 & 18.70 & 1.90 & 14.8 & 0.689 & 3.03 \\
\hline 14.1 & $110-120$ & 317.4 & 34.5 & 8.59 & 20.35 & 1.23 & 2.7 & 0.094 & 3.51 \\
\hline 17.2 & $140-150$ & 345.8 & 38.5 & 8.28 & 21.90 & 0.71 & 3.9 & 0.029 & 1.75 \\
\hline Site 568 & & & & & & & & & \\
\hline S.W. & & 0.0 & 33.1 & 8.18 & 18.47 & 2.26 & & & \\
\hline 1S-1 & & 89.4 & 27.5 & 7.73 & 13.74 & 10.91 & 5.4 & 0.533 & 7.37 \\
\hline IS-2 & & 137.2 & 27.0 & 7.82 & 14.45 & 45.42 & 8.1 & 0.720 & 7.82 \\
\hline is. -3 & & 186.2 & 23.4 & & 13.70 & & & & \\
\hline 15 -4 & & 282.3 & 19.9 & 7.91 & 11.40 & 11.15 & 6.3 & 0.745 & 0.83 \\
\hline IS-5 & & 359.4 & 28.7 & 7,38 & 16.27 & 4.67 & 18.6 & 0.481 & 0.97 \\
\hline 1S-6 & & 417.7 & 29.7 & & 16.41 & & & & \\
\hline 1.2 & $145-150$ & 3.0 & 34.1 & 7.58 & 19.12 & 41.43 & 4.9 & 0.717 & 2.59 \\
\hline $2-3$ & $145-150$ & 8.0 & & & & & & & \\
\hline $2-4$ & $145-150$ & 9.4 & 33.8 & 7.71 & 19.15 & 48.00 & 3.9 & 0.731 & 3.66 \\
\hline 3-4 & $145-150$ & 19.0 & 35.2 & 7.60 & 18.64 & 85.28 & 2.8 & 0.765 & 8.37 \\
\hline 4.3 & $145-150$ & 27.2 & 35.4 & 7.52 & 18.24 & 88.17 & 5.7 & 0.764 & 10.25 \\
\hline 5.4 & $145-150$ & 38.3 & 36.3 & 7.69 & 18.14 & 98.08 & 6.6 & 0.687 & 11.30 \\
\hline $6-4$ & $145-150$ & 48.0 & 34.9 & 7.54 & 17.09 & 118.54 & 0.7 & 0.765 & 12.52 \\
\hline 8.5 & $145-150$ & 68.6 & 33.4 & 7.61 & 16.14 & 115.95 & 2.2 & 0.834 & 12.84 \\
\hline $10-3$ & $145-150$ & 84.6 & 31.9 & 7.56 & 16.04 & 93,41 & 4.9 & 0.779 & 12.06 \\
\hline $12-3$ & $145-150$ & 103.3 & 29.7 & 7.66 & 14.45 & 84.46 & 0.6 & 0.737 & 11.43 \\
\hline 14.4 & $145-150$ & 123.8 & 27.1 & 8.09 & 13.64 & 64.69 & $\begin{array}{l}0.6 \\
1.7\end{array}$ & 0.469 & 12.02 \\
\hline $16-2$ & $145-150$ & 140.2 & 25.9 & 7.64 & 13.43 & 45.87 & 4.6 & 0.801 & 9.68 \\
\hline 18.4 & $140-150$ & 162.5 & 23.0 & 7.74 & 12.49 & 25.73 & 5.5 & 0.591 & 5.75 \\
\hline $20-3$ & $135-145$ & 180.4 & 22.6 & 7.82 & 12.79 & 20.82 & 2.6 & 0.696 & 5.04 \\
\hline 24.4 & $135-145$ & 220.7 & 23.1 & 8.02 & 13.26 & 11.47 & 7.7 & 0.652 & 1.81 \\
\hline $32-5$ & $135-145$ & 299.4 & 20.9 & 7,77 & 12.01 & 9.79 & 5.3 & 0.827 & 1.02 \\
\hline $36-4$ & $135-145$ & 336.9 & 19.8 & 7.67 & 11.44 & 10.58 & 3.9 & 0.813 & 1.05 \\
\hline $40-3$ & $135-145$ & 374.0 & 23.1 & & 13.37 & & & & \\
\hline $43-2$ & $140-150$ & 401.7 & 17.3 & 7.90 & 9.54 & 20.45 & 2.4 & 0.899 & 1,10 \\
\hline 44.4 & $135-145$ & 414.3 & 18.7 & 7.98 & 10.58 & 17.94 & 4.9 & 0.631 & 1.36 \\
\hline $43 \mathrm{~A}$ & Hydrate & 404.0 & 5.5 & & 3.21 & & & & \\
\hline $43 \mathrm{~B}$ & Hydrate & 404.0 & 5.4 & & 3.08 & & & & \\
\hline Hole 569 & & & & & & & & & \\
\hline $2-3$ & $145-150$ & 5.7 & 35.2 & 7.59 & 19.44 & 7.73 & 23.5 & 0.662 & 0.37 \\
\hline $5-3$ & $140-150$ & 34.8 & 33.1 & 7.69 & 19.44 & 28.15 & 0.4 & 0.658 & 1.85 \\
\hline $9-1$ & $140-150$ & 70.0 & 33.0 & 7.59 & 18.69 & 16.70 & 2.8 & 0.814 & 1.20 \\
\hline 13-3 & $140-150$ & 111.2 & 30.7 & 7.45 & 18.15 & 13.89 & 1.4 & 0.886 & 0.93 \\
\hline 18.2 & $140-150$ & 157.4 & 30.8 & 7.63 & 18.15 & 17.01 & 2.7 & 0.866 & 0.80 \\
\hline $23-3$ & $140-150$ & 207.1 & 29.6 & 7,43 & 19.63 & 5.93 & 1.0 & 0.875 & 0.75 \\
\hline Hole $569 \mathrm{~A}$ & & & & & & & & & \\
\hline S.W. & & 0.0 & 33.8 & 8.25 & 18.42 & 8.28 & & & \\
\hline 1.2 & $140-150$ & 249.0 & 30.2 & 7.33 & 18.42 & 9.75 & 3.0 & 0.942 & 0.83 \\
\hline Site 570 & & & & & & & & & \\
\hline $1-3$ & $140-150$ & 4.5 & 34.50 & 7.55 & 19.40 & 37.0 & 1.7 & 0.608 & 3.13 \\
\hline 4.3 & $140-150$ & 31.7 & 35.15 & 7.57 & 19,40 & 51.0 & 0.8 & 0.678 & 10.17 \\
\hline $6-5$ & $140-150$ & 53.9 & 35.18 & 7.39 & 19.00 & 52.6 & 0.5 & 0.661 & 13.01 \\
\hline $10-1$ & $140-150$ & 86.6 & 35.78 & 7.58 & 19.05 & 63.0 & 1.0 & 0.698 & 18.66 \\
\hline $16-5$ & $140-150$ & 150.5 & 33.40 & 7.60 & 18.30 & 52.0 & 1.7 & 0.739 & 18.31 \\
\hline $20-1$ & $140-150$ & 183.3 & 33.60 & 7.33 & 18.80 & 41.2 & 1.0 & 0.740 & 17.49 \\
\hline 25.3 & $140-150$ & 234.2 & 32.00 & 7.22 & 18.75 & 27.4 & 0.9 & 0.984 & 9.54 \\
\hline $30-1$ & $140-150$ & 279.5 & 25.40 & 7.43 & 14.30 & 16.0 & 1.7 & 0.861 & 3.82 \\
\hline $36-1$ & $140-150$ & 337.1 & 16.00 & 7.79 & 8.95 & 3.1 & 4.5 & 0.595 & 0.87 \\
\hline 27 & Hydrate & 249 & & & & & 0.4 & 0.047 & 0.35 \\
\hline
\end{tabular}

Note: S.W. = seawater; $1 \mathrm{~S}=$ in situ water sample. Blanks $=$ samples not available for post-cruise laboratory analysis. 


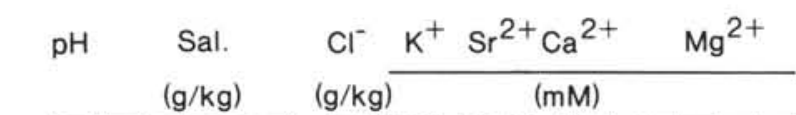

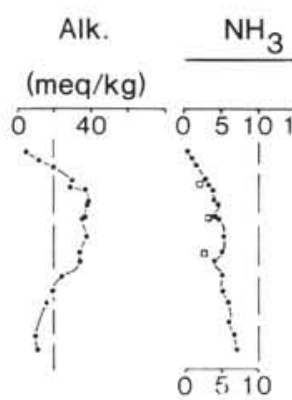

\begin{tabular}{cc}
$\mathrm{SO}_{4}{ }^{2-}$ & $\mathrm{H}_{4} \mathrm{SiO}_{4}$ \\
\hline$(\mathrm{mM})$ &
\end{tabular}

$\mathrm{Al}^{3+} \quad \delta^{18} \mathrm{O}$
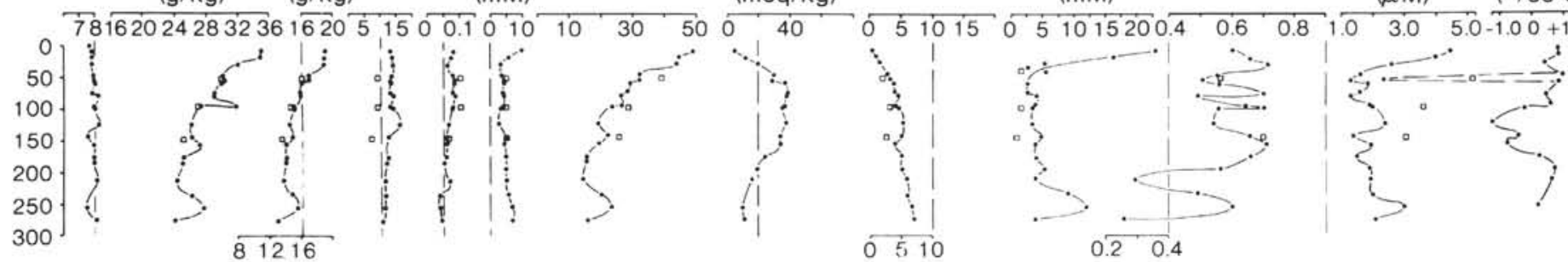

565
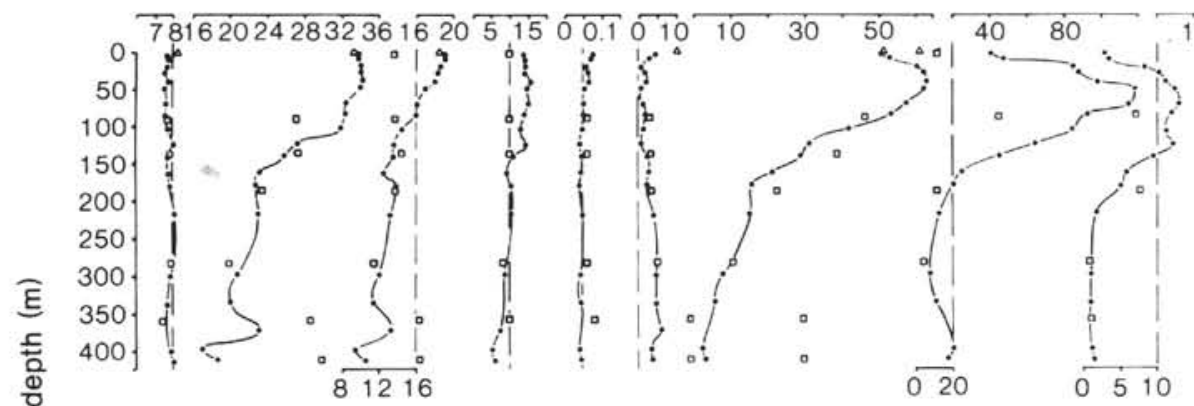

$0.2 \quad 0.4$

Eํํำ
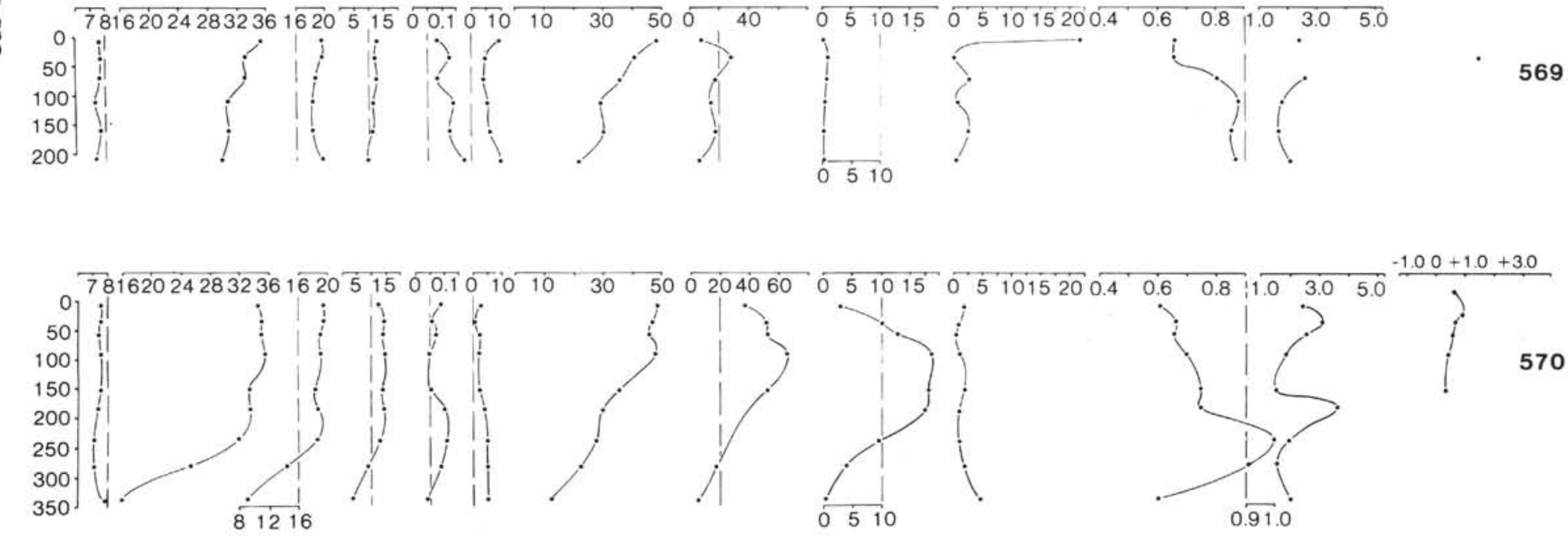

Figure 2. Interstitial water compositions for Site 565 off Costa Rica and Sites 568 to 570 on the Middle America Trench slope off Guatemala. Numbers at far left are sub-bottom depths. Squares: in situ water samples. For explanation of vertical trends, see text. 
Alkalinity has a maximum between 50 and $150 \mathrm{~m}$ subbottom, reaching $38 \mathrm{meq} . / \mathrm{kg}$. This results from the oxidation of organic matter in the sulfate-reduction and methane-production zones. A more developed maximum was observed in Holes 496 and 497 (Hesse and Harrison, 1981). A strong alkalinity maximum at these depths appears to be characteristic of hydrate-bearing sections having a pronounced chlorinity decrease and $\delta^{18} \mathrm{O}$ increase. Intense biogenic methane production required for hydrate formation seems to involve a substantial $\mathrm{CO}_{2-}$ pool from which $\mathrm{CO}_{2}$ is being reduced (e.g., Rice and Claypool, 1981). Sulfate reduction leads to $\mathrm{SO}_{4}{ }^{2-}$ concentrations of less than $5 \mathrm{mM}$ (i.e., $<5$ millimoles $/ \mathrm{dm}^{3}$ ) below $25 \mathrm{~m}$ sub-bottom depth, except in Cores 565-25 and 565-27, mentioned previously. Ammonia concentration builds up gradually from 0.26 to $7 \mathrm{mM}$ with increasing depth, as a result of the release of nitrogen from metabolized organic matter. The usual downsection decrease at greater depth was not observed in this hole, probably because of insufficient penetration.

$\mathrm{Mg}^{2+}$ concentration shows a marked downhole decrease from values near the concentration in seawater (49 $\mathrm{mM}$ in Core $565-1$ ) to about $15 \mathrm{mM}$ in the deepest sample. $\mathrm{Ca}^{2+}$ concentration decreases to about $3 \mathrm{mM}$ (i.e., to about $30 \%$ of its near-surface value) in the upper $25 \mathrm{~m}$ of the hole, from where it starts to build up slightly with depth to reach $6.5 \mathrm{mM}$ in the deepest sample. $\mathrm{K}^{+}$concentration displays minor fluctuations in the upper half of the hole and then decreases slightly downhole. The same holds for $\mathrm{Sr}^{2+}$. Dissolved-silica values are low throughout the hole $(<0.75 \mathrm{mM})$, but show marked fluctuations, as observed in many other DSDP holes (e.g., Gieskes, 1981). $\mathrm{Al}^{3+}$ was determined for the purpose of calculating stability fields in the solid fraction for clay minerals and zeolites (see Helm and Füchtbauer, this volume). It shows a substantial decrease in the upper $75 \mathrm{~m}$, from 4.4 to $1.3 \times 10^{-6} \mathrm{M}$, then shows considerable scatter below that depth.

Oxygen isotopes yield positive delta-values in the upper $95 \mathrm{~m}$ down to Core 565-10. The extreme negative value of $-3.65 \%$ for Core $565-6$ at $51 \mathrm{~m}$ sub-bottom is probably caused by analytical error. In the interval from 97 to $170 \mathrm{~m}$ (Cores 565-11 to 565-17), values are negative, with a minimum of $-1.26 \%$ for $\delta^{18} \mathrm{O}$ (SMOW) at $118 \mathrm{~m}$ (Core 565-13). From $175 \mathrm{~m}$ (Core 565-19) to the deepest analyzed sample at $252 \mathrm{~m}$ sub-bottom (Core 56527), positive values persist, with a maximum of $+0.77 \%$ at $193 \mathrm{~m}$ (Core 565-21).

Three in situ water samples were recovered from subbottom depths of 52,98 , and $144 \mathrm{~m}$. Compared with nearby samples, obtained with the routine shipboard squeezing technique, salinity values are almost identical; chlorinity, $\mathrm{K}^{+}, \mathrm{NH}_{4}{ }^{+}$, and $\mathrm{SO}_{4}{ }^{2-}$ concentrations are slightly lower, and $\mathrm{Sr}^{2+}, \mathrm{Ca}^{2+}, \mathrm{Mg}^{2+}$, and $\mathrm{H}_{4} \mathrm{SiO}_{4}$ values are slightly higher. Only $\mathrm{Al}^{3+}$ shows considerable enrichment, by up to a factor of 3 , compared with routine samples.

The data obtained at this site are complex, particularly with respect to the distribution of $\delta^{18} \mathrm{O}$ in the pore fluids. $\delta^{18} \mathrm{O}$ shows a well-defined minimum, in a zone characterized by low chlorinity. In a subsequent section we shall address this problem in greater detail, especially with regard to the hydrate-decomposition hypothesis.

\section{Sites 566 to 570: Middle America Trench Slope Off Guatemala}

\section{Site 566}

This site lies in $3675 \mathrm{~m}$ of water; drilling penetrated to $136.6 \mathrm{~m}$ sub-bottom depth. No evidence for gas hydrates was found in the sediments, and only three interstitial water samples were collected. Analytical results are included in Table 1, but will not be discussed, since no anomalous behavior was recognized. Interstitial water samples were obtained to a depth of only $15 \mathrm{~m}$ subbottom, not throughout the hole, thus making interpretations impossible. Gas hydrates, however, are probably present in fractures of serpentinite encountered at the bottom of the hole. Gas released from chips of ice-like material from these fractures shows an exponential decrease for hydrocarbons larger than isobutane, indicating a hydrate source (Kvenvolden and McDonald, this volume).

\section{Site 567}

Site 567 lies in $5529 \mathrm{~m}$ of water; drilling penetrated to a depth of $501 \mathrm{~m}$. The site is in the vicinity of Site 494 of Leg 67. Interstitial water samples were obtained below a depth of $200 \mathrm{~m}$ sub-bottom. At Site 494, the interstitialwater profile of $\mathrm{Ca}^{2+}$ showed a sharp increase below $200 \mathrm{~m}$, with a simultaneous decrease in $\mathrm{Mg}^{2+}$ (Harrison et al., 1982). The data for $\mathrm{Ca}^{2+}$ and $\mathrm{Mg}^{2+}$ in Table 1 confirm this observation, and indicate a very large increase in $\mathrm{Ca}^{2+}$ below $310 \mathrm{~m}$ and a complete depletion in $\mathrm{Mg}^{2+}$ at the base of the hole. We suggest that this can be understood best in terms of interactions with the underlying basement rocks, probably by diffusive exchange. Similar findings were made at Site 493 of Leg 66 (Gieskes et al., this volume). Chloride concentrations increase slightly with depth, a phenomenon often observed when exchange with underlying basement is considered to be important (McDuff, 1978).

\section{Site 568}

This site, in the immediate vicinity of gas-hydratebearing Site 496 of Leg 67 (Harrison et al., 1982), lies in $2031 \mathrm{~m}$ of water; drilling penetrated to a total depth of $417 \mathrm{~m}$. The main sediment type is olive-gray Quaternary to lower Miocene diatomaceous mud and mudstone with rare beds of diagenetic carbonate up to $10 \mathrm{~cm}$ thick. Because of the expected hydrate effects, closely spaced porewater samples were taken. The analytical results principally duplicate those for Site 496 .

\section{Interstitial Water Chemistry}

Salinity and chlorinity decrease downsection from Sal. $=34 \mathrm{~g} / \mathrm{kg}$ and $\mathrm{C} \ell^{-}=19 \mathrm{~g} / \mathrm{kg}$ to Sal. $=17.3 \mathrm{~g} / \mathrm{kg}$ and $\mathrm{C}^{-}=9.5 \mathrm{~g} / \mathrm{kg}$-that is, to about half the local bottom-water values. The downsection decrease is not entirely smooth. In the upper $50 \mathrm{~m}$, salinity shows a slight increase related to the strong alkalinity and $\mathrm{Mg}^{2+}$ maxima at this level. Cores 568-40 and 568-44, from the 
bottom of the hole, show increases compared with the samples immediately above. These increases could be due to infiltration of seawater in the drilling process, although this kind of contamination rarely occurs.

Alkalinity reaches a maximum of $118 \mathrm{meq} . / \mathrm{kg}$ at 50 $\mathrm{m}$ sub-bottom in Core 568-6, which almost perfectly matches the record alkalinity reported for Hole 496 (Harrison et al., 1982). Below this depth, a pronounced downsection decrease to less than 10 meq. $/ \mathrm{kg}$ is observed. As stated for Site 565 , this alkalinity maximum reflects vigorous microbial metabolism of organic matter, which appears to be a prerequisite for generation of methane in quantities sufficient for hydrate formation. For the downsection alkalinity decrease below $50 \mathrm{~m}$, the possible sink is carbonate reduction (leading to methane production) coupled with carbonate precipitation. In a system buffered near neutral $\mathrm{pH}$, carbon dioxide reduction alone cannot change alkalinity $\left(2 \mathrm{HCO}_{3}^{-} \rightarrow \mathrm{CO}_{2}+\right.$ $\mathrm{CO}_{3}{ }^{2-}+\mathrm{H}_{2} \mathrm{O}$ ), but the conversion of $\mathrm{CO}_{2}$ to $\mathrm{CH}_{4}$ raises the $\mathrm{pH}$, which would enable carbonate precipitation and thus lower the alkalinity (Claypool and Kaplan, 1974). Dolomite and more complex Mn-Fe carbonates may be precipitated at these sub-bottom depths (e.g., Froelich et al., 1979; Kelts and McKenzie, 1982; Suess, 1979). Although $\mathrm{Mn}$ and Fe were not analyzed in Leg 84 pore waters, the precipitation of complex carbonates is a realistic possibility (Tassé and Hesse, in press). Release of hydrate water will, of course, also contribute to the downsection alkalinity decrease.

Ammonia displays a downhole trend similar to that of alkalinity. The upper maximum, however, is broader and not nearly so pronounced as for alkalinity. The decrease below $125 \mathrm{~m}$ (Core 568-14) may be due to uptake in exchange positions by clay minerals at the time when $\mathrm{Mg}^{2+}$ is precipitated in carbonates. Sulfate is reduced to a level of less than $5 \mathrm{mM}$ in the topmost core. Deeper cores show some scatter. About half of the analyses yield values below $3 \mathrm{mM}$, but some range between 3 and 7 $\mathrm{mM}$. Some of these higher concentrations may be due to seawater contamination.

The $\mathrm{Mg}^{2+}$ and $\mathrm{Ca}^{2+}$ curves are best explained by the effects of carbonate precipitation and dilution by released hydrate water. The strong upper maximum for $\mathrm{Mg}^{2+}(63 \mathrm{mM})$ matches that in Hole 496. At these shallow depths, ammonia may expel $\mathrm{Mg}^{2+}$ to the pore waters from exchange positions in clay minerals (Moore and Gieskes, 1980). The strong decrease in the $\mathrm{Mg}^{2+}$ concentration below $50 \mathrm{~m}$, on the other hand, indicates dolomite (and perhaps other complex carbonate) precipitation, which lowers the carbonate alkalinity and prevents an increase in the $\mathrm{Ca}^{2+}$ concentration. $\mathrm{Ca}^{2+}$ concentration remains below $5 \mathrm{mM}$ all the way down to the bottom of the hole, except for Core 568-40, in which this value is slightly exceeded.

$\mathrm{K}^{+}$shows a slight maximum in the upper part of the hole, followed by a downsection decrease from about 15 $\mathrm{mM}$ to about half that value in the deeper parts. This decrease could in part be accounted for by the dilution effect from hydrate water alone (Fig. 3). The same holds for the $\mathrm{Sr}^{2+}$ concentration in the upper $125 \mathrm{~m}$, which

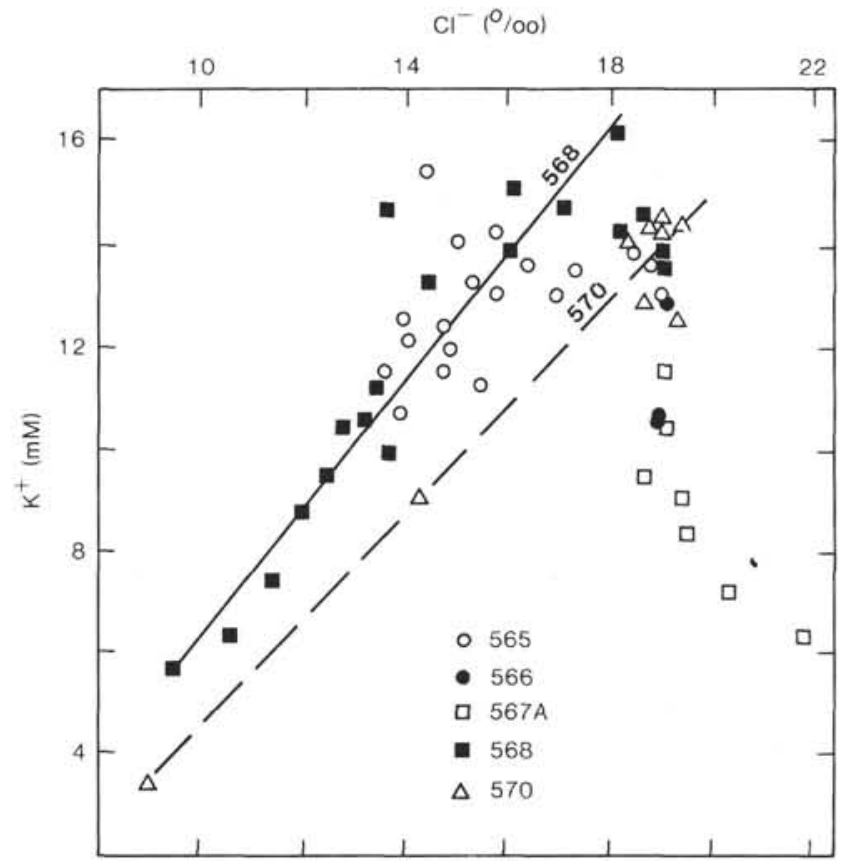

Figure 3. Plot of $\mathrm{K}^{+}$vs. $\mathrm{Cl}^{-}$. For gas-hydrate-bearing Sites 568 and 570 there is a good linear correlation, suggesting that the downhole decrease in $\mathrm{K}^{+}$concentration is a dilution effect caused by water released from hydrates. At hydrate-free Holes 566 and 567A, other mechanisms operate to decrease the $\mathrm{K}^{+}$concentration.

decreases from 0.1 to $0.05 \mathrm{mM}$; below $125 \mathrm{~m}$ it stays almost constant.

$\mathrm{Al}^{3+}$ and silica concentrations vary downhole. In this hole $\mathrm{Al}^{3+}$ appears to be negatively correlated with $\delta^{18} \mathrm{O}$, and may thus reflect a dilution effect by hydrate water.

$\delta^{18} \mathrm{O}$ values are positive throughout the hole, except for one sample from Section 568-2-3, which showed a value of $-0.09 \%$. Below $90 \mathrm{~m}$, the downward trend of $\delta^{18} \mathrm{O}$ is smooth, and reaches a value of $+3.3 \%$ at $400 \mathrm{~m}$ sub-bottom. Shipboard scientists (site chapter, this volume) recognized the presence of hydrates below $190 \mathrm{~m}$, especially because of the change in gas composition from a pattern with a wide range of hydrocarbon species $\left(\mathrm{C}_{1}-\mathrm{C}_{6}\right)$ above this depth to a pattern dominated by $\mathrm{C}_{1}$ and $\mathrm{C}_{2}$ below. The presence of hydrates in the upper 190 $\mathrm{m}$ is suspected not only because of decreased chloride concentrations but also because of the transparent section on the seismic reflection profile (GUA-13, Ibrahim et al., 1979) for this site, which indicates that hydratebearing sediments extend upward close to the seafloor.

In situ water samples in the upper part of the hole, between 90 and $280 \mathrm{~m}$ sub-bottom, give results very similar to those from samples taken nearby and squeezed on board. Below $350 \mathrm{~m}$, in situ samples have significantly higher chlorinity, salinity, and $\mathrm{Ca}^{2+}$ and $\mathrm{Mg}^{2+}$ concentrations than squeezed samples (Fig. 2). This is most likely an artifact caused by the intrusion of seawater, because sulfate concentration in the sample from $360 \mathrm{~m}$ sub-bottom reaches $18.6 \mathrm{mM}$, indicating contamination.

Water recovered directly from decomposed hydrates that were retrieved from below $400 \mathrm{~m}$ yielded a chlorini- 
ty of $3.2 \mathrm{~g} / \mathrm{kg}$ and a salinity of $5.5 \mathrm{~g} / \mathrm{kg}$ (site chapter, this volume).

\section{Site 569}

Two holes, 569 and 569A, were drilled at this site in water depths of 2744 and $2795 \mathrm{~m}$, respectively. Hole 569 penetrated $251 \mathrm{~m}$ of sediment. Hole 569A was cored from 246 to $365 \mathrm{~m}$ sub-bottom, and reached igneous basement at $351 \mathrm{~m}$. The sedimentary sequence comprises a succession of Pleistocene to lower Eocene green muds and mudstones, with suspected unconformities between the upper Pliocene and the Miocene, between the upper Oligocene and Eocene, and between the Eocene and basement. The Oligocene mudstones are calcareous; the Eocene includes green and black siliceous mudstone and blue-gray mudstone.

\section{Interstitial Water Chemistry}

Only six samples covering the upper $210 \mathrm{~m}$ of Hole 569 were analyzed. Downsection salinity decreases (to $29.6 \mathrm{~g} / \mathrm{kg}$ ) are minor. Chlorinity is about the same at the bottom of the hole as at the top, and shows a slight decrease in between. This decrease is too small to be identified with the occurrence of hydrates. The alkalinity maximum of $28 \mathrm{meq} . / \mathrm{kg}$ at $35 \mathrm{~m}$ sub-bottom is much smaller than at Site 568. Ammonia concentration stays uniformly low (less than $1.85 \mathrm{mM}$ ). Sulfate reduction is complete in the second sample at $32 \mathrm{~m}$ (Core 569-4). $\mathrm{Mg}^{2+}$ concentration decreases to about half its near-surface value in the deepest sample, and $\mathrm{Ca}^{2+}$ concentration first decreases and then increases downhole. The concentration of $\mathrm{Sr}^{2+}$ increases downhole with fluctuations. $\mathrm{K}^{+}$shows a slight decrease in concentration.

Pore-water chemistry provides no clear evidence for the presence of gas hydrates at this site, but the transparency of the upper section on the seismic profile GUA13 (Ibrahim et al., 1979) makes the occurrence of a hydrate zone possible, although no bottom-simulating reflector is present. Samples for isotopic analyses were not available for this site. The rather monotonous downhole trends in the water chemistry do not indicate significant diagenetic reactions occurring at present, except, perhaps, for minor carbonate precipitation.

\section{Site $\mathbf{5 7 0}$}

Site 570 is on the upper slope in $1700 \mathrm{~m}$ of water; drilling here penetrated $374 \mathrm{~m}$ of Pleistocene to lower Eocene sediments. The sediments overlie igneous basement, in which $28 \mathrm{~m}$ of serpentinized peridotite and serpentinite were cored. The Pleistocene to Miocene sedimentary succession consists of green mud and mudstone with layers of sandstone, pebbly sandstone, and pebbly mudstone. The Miocene unconformably overlies a lower Eocene light green siliceous limestone and grayish-greenish sandstone with red pebble horizons at the base. Another unconformity occurs between the Pliocene and the upper Miocene.

\section{Interstitial Water Chemistry}

Nine widely spaced water samples were taken over a total sub-bottom distance of $337 \mathrm{~m}$. They show relatively minor decreases in chlorinity and salinity down to sample 7 at $234 \mathrm{~m}$ sub-bottom, below which a drastic decrease in both chlorinity (from 18.75 to $9 \mathrm{~g} / \mathrm{kg}$ ) and salinity (from 32.0 to $16.0 \mathrm{~g} / \mathrm{kg}$ ) occurs. The top of the zone of this rapid decrease coincides with the interval from which a 1.05 -m-thick layer of almost pure gas hydrate was recovered (in Core 570-27, at about $250 \mathrm{~m}$ subbottom; see Plate 1), which according to the geophysical logs stems from a 4-m layer of massive hydrate at the Pliocene/upper Miocene unconformity (site chapter, this volume). The first visual evidence for hydrates was obtained from a frozen ash layer at $192 \mathrm{~m}$ (Core 570-21). It is interesting that this layer is not associated with a strong pore-water signal.

There is an alkalinity maximum of $63 \mathrm{meq} . / \mathrm{kg}$ in Core 570-10 at $87 \mathrm{~m}$ sub-bottom, and at the same depth ammonia concentration shows the strongest maximum $(18.7 \mathrm{mM})$ of all Leg 84 sites. Sulfate concentration is uniformly low, except in the bottom sample, where it reaches $4.5 \mathrm{mM}$, probably as a result of seawater contamination.

$\mathrm{Mg}^{2+}$ concentration decreases markedly from $49 \mathrm{mM}$ at the top to $12 \mathrm{mM}$ in the deepest sample; $\mathrm{Ca}^{2+}$ concentration increases slightly downhole, following the pattern established for the other holes on the Guatemala Trench slope. The concentration of $\mathrm{K}^{+}$decreases from a maximum of $14.5 \mathrm{mM}$ in Core $570-10$ to $3.3 \mathrm{mM}$ in the deepest sample, but concentrations of $\mathrm{Sr}^{2+}, \mathrm{H}_{4} \mathrm{SiO}_{4}$, and $\mathrm{Al}^{3+}$ vary unsystematically. Oxygen isotopic analyses are available only for the upper six samples (down to Core $570-16$ at $150 \mathrm{~m}$ sub-bottom), that is for the interval above the strong chlorinity decrease. Values are slightly positive, but decrease with depth. Small amounts of hydrate may be present near the top of the hole, but the associated chlorinity decrease is too small for proof.

Water from the decomposed massive hydrate at 250 $\mathrm{m}$ sub-bottom had a chlorinity of $0.65 \mathrm{~g} / \mathrm{kg}$, an alkalinity of $2.47 \mathrm{meq} . / \mathrm{kg}$, a Ca ${ }^{2+}$ concentration of $0.25 \mathrm{mM}$, and an $\mathrm{Mg}^{2+}$ concentration of $0.16 \mathrm{mM}$ (site chapter, this volume).

\section{DISCUSSION}

As mentioned in the Introduction, the interstitial-water chemistry of Leg 67 led to the gas-hydrate decomposition hypothesis (Hesse and Harrison, 1981; Harrison et al., 1982). In this hypothesis it is postulated that any decrease in chlorinity in methane-bearing sediments (often accompanied by an increase in the $\delta^{18} \mathrm{O}$ of interstitial waters) is the result of the sampling procedure by which routine interstitial water samples are obtained. Samples of sediment are brought to the ship, and then a small portion of about $200 \mathrm{~cm}^{3}$ is treated in a stainless steel squeezer to extract interstitial waters. If gas hydrates are present, these will presumably decompose to greater or smaller extents, releasing hydrate water, which is isotopically heavy and free of dissolved salts, and thus causing decreases in chloride and increases in the $\delta^{18} \mathrm{O}$ of the interstitial water. During Leg 84 , use was made of the Barnes-Uyeda in situ water sampler, with the intent to sample true interstitial water samples, less affected by this process. The results presented for Sites 565 and 568, 
however, clearly indicate very good agreement with data obtained from the normal extraction procedure. This observation, of course, raises some important questions. Is the good agreement between in situ samples and shipboard squeezing results due to identical processes? Or are the observations on the chloride concentration-vs.depth profiles real and caused by the presence of a pool of low-chlorinity water (high in $\delta^{18} \mathrm{O}$ ) below the bottomsimulating reflector (BSR), the $\mathrm{Cl}^{-}$and $\delta^{18} \mathrm{O}$ profiles being due to diffusion?

In Figure 4 we present the profiles of chlorinity for Sites 496 and 568. The profiles are very similar, and show the largest decreases in the upper, rapidly accumulated Quaternary section (0-220 m sub-bottom at Site 496). This zone of high organic carbon content (Harrison et al., 1982) is presumably also the zone of highest methane gas production. If no significant upward advection of water from below the BSR were to occur and if the chloride profiles were the result of diffusion of $\mathrm{Cl}^{-}$to the low-chlorinity water pool below, a profile close to the dash-dot line in Figure 4 would result, in analogy with the profiles for Sites 371 and 374 of Leg $42 \mathrm{~A}$, where chloride diffused from an evaporite source buried in the sediments (McDuff et al., 1978). We therefore submit that upward advection of water from below is in fact insignificant in this area of thick sediment cover, and that the gradual decrease in chloride results from the rather uniform presence of gas hydrates in these sediments, with a slow increase in hydrate concentrations below $200 \mathrm{~m}$. Often more jagged profiles are seen in chloride-vs.-depth distributions, with minima of chloride in hydrate-bearing zones (Jenden and Gieskes, 1983; Gieskes et al., this volume). These can best be understood in terms of uneven distributions of hydrates, the low-chloride zones resulting from decomposition of hydrates. This observation further supports our assumption that advection or diffusion of low-chlorinity water from below was not important.

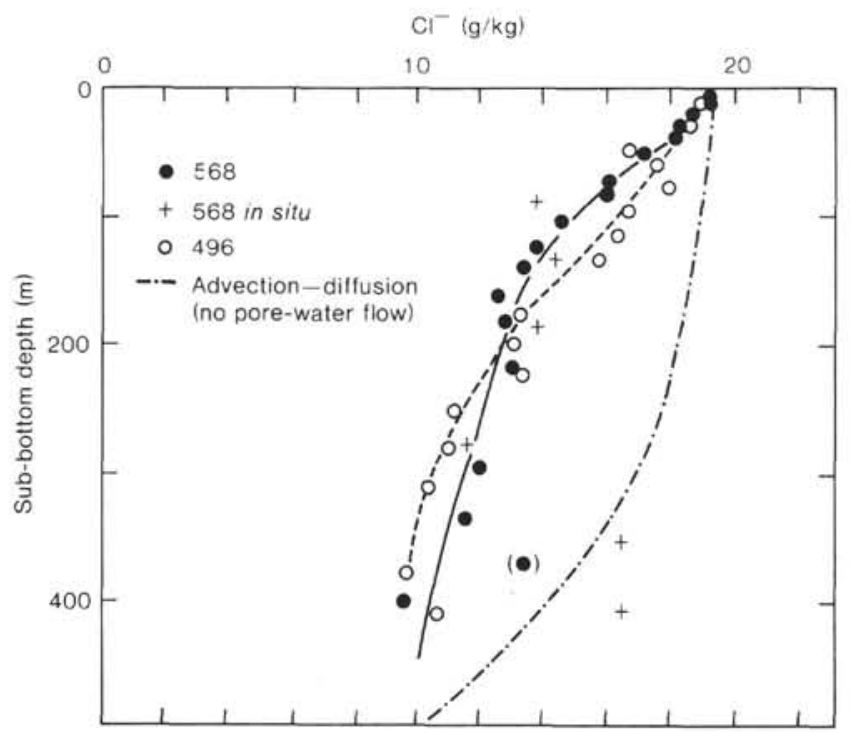

Figure 4. Depth-vs.-chlorinity profiles for Sites 496 (Leg 67) and 568, including in situ pore-water samples.
We suggest, therefore, that the hydrate-decomposition hypothesis is the most reasonable explanation for observed decreases in chlorinity. The reason that the in situ data are close to those obtained from shipboard squeezing samples is presumably the pressure drop from the sampler into the surrounding sediment. This pressure drop, after all, is a prerequisite for water flow into the sampling device. With a porosity of $50 \%$, a volume of only 500 to $1000 \mathrm{~cm}^{3}$ of sediment is involved in the immediate surroundings of the sample port. A true test for actual formation water could possibly be carried out in the future by means of high-pressure gas displacement of pore fluids through a sample obtained with the DSDP pressure core barrel.

With the conclusion about the essential correctness of the hydrate-decomposition hypothesis, we will now examine the relationship between decreases in chlorinity and changes in the $\delta^{18} \mathrm{O}$ composition of interstitial waters. Figure 5 presents these relationships for Sites 496 (Harrison et al., 1982), 565, 568, and 570. No simple correlation seems to prevail at any of these sites, though previous estimates for Site 496 revealed a possible linear correlation (Harrison et al., 1982). Appreciable scatter appears in the $\delta^{18} \mathrm{O}$ data, but there is little doubt about the trends.

The only exception is Site 565 , where a clear minimum in $\delta^{18} \mathrm{O}$ is evident. The decomposition of hydrates would support increases in $\delta^{18} \mathrm{O}$ unless the hydrates were formed under conditions of low $\delta^{18} \mathrm{O}$ in the original interstitial waters. The concentration-vs.-depth profiles (Fig. 2) indicate a $\delta^{18} \mathrm{O}$ minimum between 100 and 180 $\mathrm{m}$, that is, in a zone of continued decrease of chlorinity. We suggest that this phenomenon can be explained in terms of decreases in $\delta^{18} \mathrm{O}$ resulting from in situ altera-

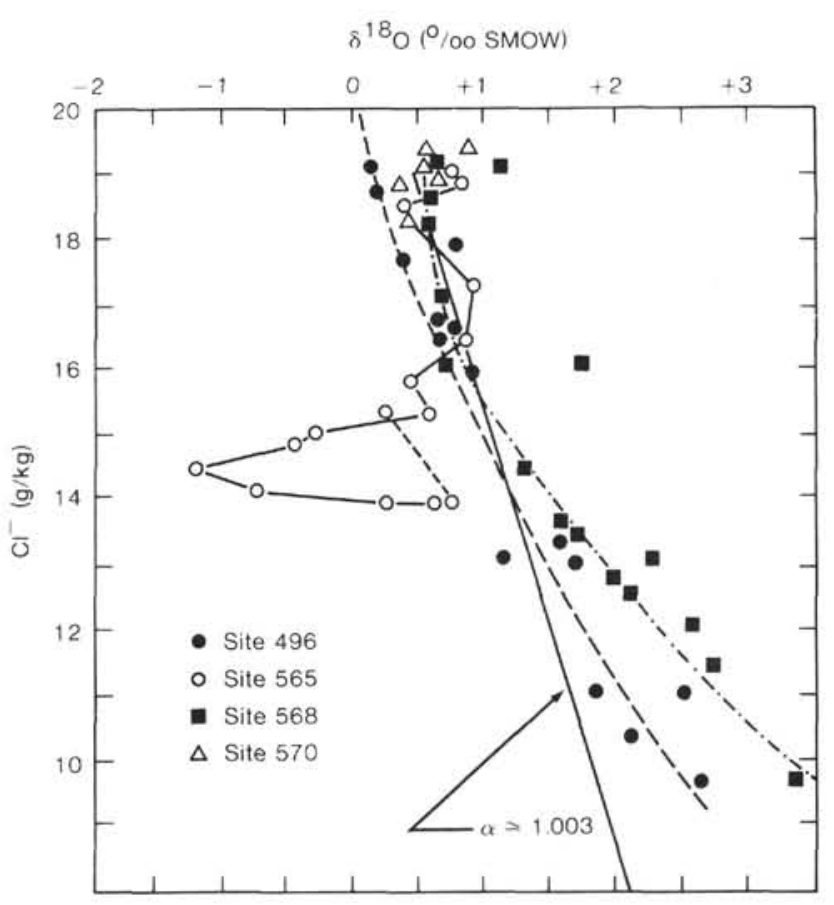

Figure 5. Chlorinity-oxygen-isotope correlations. 
tion of volcanic material. This signal then would either superimpose itself on the increase in $\delta^{18} \mathrm{O}$ caused by hydrate decomposition, or might be reflected in relatively low $-\delta^{18} \mathrm{O}$ hydrate water. Jenden and Gieskes (1983) also found a complex relationship between $\mathrm{Cl}^{-}$and $\delta^{18} \mathrm{O}$ at Site 533 in the Blake Outer Ridge hydrate zone. There, a good correlation between $\delta^{18} \mathrm{O}$ and deuterium $(D)$ was also found. Naturally, if a variety of processes affects the distribution of oxygen and hydrogen isotopes, then the distribution of $\delta^{18} \mathrm{O}$ is not a good indicator to test the hydrate-decomposition hypothesis. Chlorinity is probably the most reliable for these purposes. On the other hand, chlorinity might also be lowered by the inflow of meteoric waters from continental aquifers, so that other evidence for hydrate decomposition would be needed. In this case, $\delta^{18} \mathrm{O}$ values would decrease. Therefore, where both chlorinity and oxygen isotopic composition of the pore waters result from more than one possible process, we can presently not separate the relative contributions of each of them.

With respect to Site 565 , therefore, we face two possibilities. Gas hydrates may be absent in the zone of the $\delta^{18} \mathrm{O}$-minimum between about 95 and $170 \mathrm{~m}$ sub-bottom depth, and the negative $\delta^{18} \mathrm{O}$ values, as well as the low chlorinity (less than $16 \mathrm{~g} / \mathrm{kg}$ ), might be due to the influx of meteoric water from an aquifer under the fore-arc basin off Costa Rica. This would be in accordance with the shipboard observation of high gas concentration in the cores only below $175 \mathrm{~m}$ (site chapter, this volume), and would be a significant finding, since meteoric water influx to the ocean from continental sources at such depths on the continental margins has only rarely been reported (e.g., Site 241, Gieskes, 1974).

The alternative-a more continuous distribution of gas hydrates throughout Hole 565, increasing gradually in concentration with depth-is more attractive, however, because of the relatively smooth chloride-vs.-depth profile and the systematic downsection variations in most of the other ions analyzed. Influx of pore waters fros. continental aquifers at depths between 3 and $4 \mathrm{~km}$ would involve brines with chlorinities considerably higher than fresh water and would therefore not explain the lowered chloride contents. An exception to this may be Site 241 (Gieskes, 1974) off the Somali coast.

The correlation between $\mathrm{Cl}^{-}$and $\delta^{18} \mathrm{O}$ for Sites 496 and 568 shows a trend of increasing $\delta^{18} \mathrm{O}$ with decreasing $\mathrm{Cl}^{-}$. Although this correlation should be linear, the trends in Figure 5 appear to be associated with curvature, especially for Site 568. Of interest is establishment of the probable fractionation factor for oxygen isotopes in the water-gas-hydrate system to explain these trends. For pure ice this factor is 1.003 (O'Neil, 1968), and for the formation of tetrahydrofuran hydrate a value of 1.0027 is obtained (Davidson et al., 1983). For methane hydrate the fractionation factor is expected to be very close to that for the tetrahydrofuran hydrate. This is implied by the trend line marked by $\alpha=1.003$ in Figure 5 . Any values of $\delta^{18} \mathrm{O}$ heavier than suggested by the trend line would then need further explanation. One possible explanation may be the occurrence of multiple fractionation in the lower part of the hydrate zone. If the base of the hydrate zone migrates vertically with time-for example, as a result of heat-flow variations - then heavy$\delta^{18} \mathrm{O}$ water could be released, which could again be used to form new, heavier hydrates. For a $50 \%$ reduction in chlorinity, as measured at the bottoms of holes 496 and 568 , the $\delta^{18} \mathrm{O}$ value expected from a single-stage fractionation would be about $+1.4 \%$, rather than the observed values of +2.6 and $+3.3 \%$, respectively, suggesting that for the oxygen isotopes multiple fractionation affects a more than 100-m-thick sediment zone near the hydrate base, or, conversely, that the chloride fractionation mechanism is less efficient in the deeper part of hydrate zones. This might be caused by chloride ions trapped between rapidly formed hydrate crystals, and could explain the nonlinear trends with depth of the $\delta^{18} \mathrm{O}$-vs.- $\mathrm{Cl}^{-}$curves. This, of course, would not be easy to test, but certainly would yield the observed trend in $\mathrm{Cl}^{-}$versus $\delta^{18} \mathrm{O}$.

Though our data do not allow us to propose a final model for the formation of gas hydrates, the data obtained during Leg 84 do serve two purposes. We have established that the gas-hydrate decomposition hypothesis is eminently reasonable. We have demonstrated evidence for extra complications in the $\mathrm{Cl}-\delta^{18} \mathrm{O}$ relationship, resulting both from possible alteration of volcanic matter, leading to lower $\delta^{18} \mathrm{O}$, and also from a multiple fractionation leading to $\delta^{18} \mathrm{O}$ values heaver than expected.

\section{ACKNOWLEDGMENTS}

Financial support for this project came from the National Science and Engineering Research Council of Canada, grant A7368 to R. Hesse and grant A4265 to J. Lebel. J. Gieskes was supported by NSF Grant OCE-82-18539. Shipboard chemical analyses were carried out by Dennis Graham. Critical reviews of the paper were provided by P. Jenden, K. A. Kvenvolden, and an anonymous reviewer. A. Kosowski did the typing and R. Yates drafted the figures. This support and assistance is gratefully acknowledged.

\section{REFERENCES}

Barnes, R. O., Gieskes, J. M., Horvath, J., and Akijama, W., 1979. Interstitial water studies, Legs 47A, B. In Sibuet, J.-C., Ryan, W. B. F., et al., Init. Repts. DSDP, 47, Pt. 2: Washington (U.S. Govt. Printing Office), 577-581.

Claypool, G. E., and Kaplan, I. R., 1974. The origin and distribution of methane in marine sediments. In Kaplan, I. R. (Ed.), Natural Gases in Marine Sediments. Mar. Sci., 3:99-139.

Davidson, D. W., Leaist, D. G., and Hesse, R., 1983. Oxygen-18 enrichment in the water of a clathrate hydrate. Geochim. Cosmochim. Acta, 47:2293-2295.

Epstein, S. and Mayeda, T., 1953. Variation of ${ }^{18} \mathrm{O}$ content of waters from the natural sources. Geochim. Cosmochim. Acta, 4:213-224.

Froelich, P. N., Klinkhammer, G. P., Bender, M. L., Luedtke, N. A., Heath, G. R., Cullen, D., Dauphin, P., Hammond, D., Hartman, B., and Maynard, V., 1979. Early oxidation of organic matter in pelagic sediments of the eastern equatorial Atlantic: suboxic diagenesis. Geochim. Cosmochim. Acta, 43:1075-1090.

Gieskes, J. M., 1974. Interstitial water studies, Leg 25. In Simpson, E. S. W., Schlich, R., et al., Init. Repts. DSDP, 25: Washington (U.S. Govt. Printing Office), 361-394.

1981. Deep sea drilling interstitial-water studies: Implications for chemical alteration of the ocean crust, Layers I and II. In Warme, J. E., Douglas, R. G., and Winterer, E. L. (Eds.), The Deep Sea Drilling Project: A Decade of Progress, Soc. Econ. Paleontol. Mineral. Spec. Publ., 32:149-167.

Gieskes, J. M., and Lawrence, J. R., 1976. Interstitial water studies, Leg 35. In Hollister, C. D., Craddock, C., et al., Init. Repts. DSDP, 35:Washington (U.S. Govt. Printing Office), 407-424. 
Harrison, W. E., and Curiale, J. A., 1982. Gas hydrates in sediments of Holes 497 and 498A, Deep Sea Drilling Project, Leg 67. In Aubouin, J., von Huene, R., et al., Init. Repts. DSDP, 67: Washington (U.S. Govt. Printing Office), 591-594.

Harrison, W. E., Hesse, R., and Gieskes, J. M., 1982. Relationship between sedimentary facies and interstitial water chemistry in slope, trench and Cocos Plate sites from the Mid-America Trench transect, active margin off Guatemala. Leg 67, DSDP. In Aubouin, J., von Huene, R., et al., Init. Repts. DSDP, 67: Washington (U.S. Govt. Printing Office), 603-614.

Hesse, R., and Harrison, W. E., 1981. Gas-hydrates (clathrates) causing pore-water freshening and oxygen isotope fractionation in deepwater sedimentary sections of the terrigenous continental margins. Earth Planet. Sci. Lett., 55(3):453-462.

Ibrahim, A. K., Latham, G. V., and Ladd, J., 1979. Seismic refraction and reflection measurements in the Middle America Trench offshore Guatemala. J. Geophys. Res., 84(B10):5643-5649.

Jenden, P. D., and Gieskes, J. M., 1983. Chemical and isotopic composition of interstitial water from Deep Sea Drilling Project Sites 533 and 534. In Sheridan, R. E., Gradstein, F. M., et al., Init. Repts. DSDP, 76: Washington (U.S. Govt. Printing Office), 453-461.

Kelts, K., and McKenzie, J. A., 1982. Diagenetic dolomite formation in Quaternary anoxic diatomaceous muds of Deep Sea Drilling Project Leg 64, Gulf of California. In Curray, J. R., Moore, D. G., et al., Init. Repts. DSDP, 64, Pt. 2: Washington (U.S. Govt. Printing Office), 553-569.

McDuff, R. E., 1978. Conservative behaviour of calcium and magnesium in interstitial waters of marine sediments: Identification and interpretation [Ph.D. thesis]. Univ. of Calif., San Diego (Scripps Institution of Oceanography).

McDuff, R. E., Gieskes, J. M., and Lawrence, J. R., 1978. Interstitial water studies, Leg 42A. In Hsü, K. J., Montadert, L., et al., Init.
Repts. DSDP, 42, Pt. 1: Washington (U.S. Govt. Printing Office), 561-568.

Manheim, F. T., and Sayles, F. L., 1974. Composition and origin of interstitial waters of marine sediments, based on deep sea drill cores. In Goldberg, E. D. (Ed.), The Sea (Vol. 5) Marine Chemistry: New York, London, Sydney, Toronto (Wiley-Interscience), 527-568.

Moore, G. W., and Gieskes, J. M., 1980. Interaction between sediment and interstitial water near the Japan Trench, Leg 57, Deep Sea Drilling Project. In Scientific Party, Init. Repts. DSDP, 56, 57, Pt. 2: Washington (U.S. Govt. Printing Office), 1269-1275.

O'Neil, J. R., 1968. Hydrogen and oxygen isotope fractionation between ice and water. J. Phys. Chem., 72(1): 3683-3684.

Presley, B. J., and Claypool, G. E., 1971. Techniques for Analyzing Interstitial Water Samples. I. Determination of Minor and Major Constituents: Washington (U.S. Govt. Printing Office).

Rice, D. D., and Claypool, G. E., 1981. Generation, accumulation, and resource potential of biogenic gas. Am. Assoc. Pet. Geol. Bull., 65(1): 5-25.

Shipley, T. H., and Didyk, B. M., 1982. Occurrence of methane hydrates offshore southern Mexico. In Watkins, J. S., Moore, J. C., et al., Init. Repts. DSDP, 66: Washington (U.S. Govt. Printing Office), 547-555.

Suess, E., 1979. Mineral phases formed in anoxic sediments by microbial decomposition of organic matter. Geochim. Cosmochim. Acta, 43:339-352.

Tassé, N., and Hesse, R., in press. Origin and significance of complex authigenic carbonates in Cretaceous black shales of the West Alps. J. Sediment. Petrol., 54(3).

Date of Initial Receipt: 4 September 1983 Date of Acceptance: 6 August 1984 


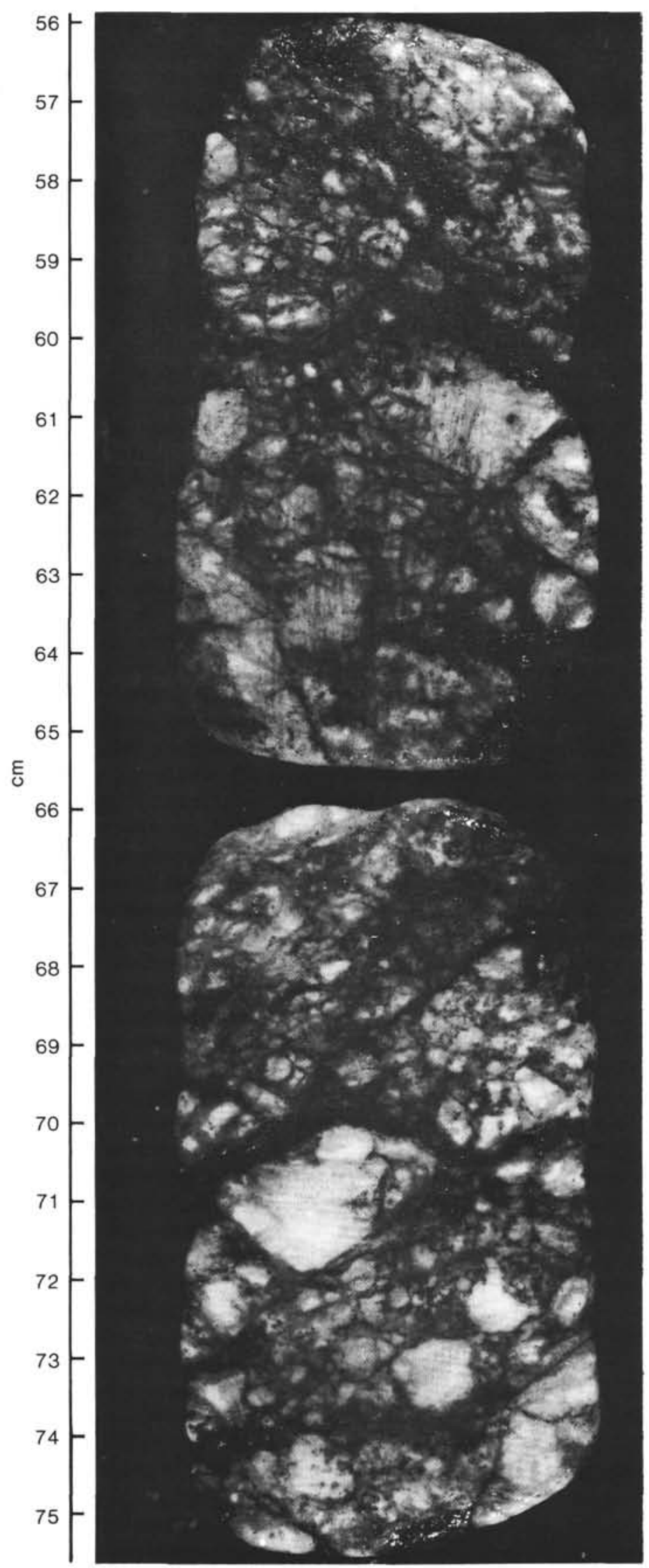

Plate 1. Massive hydrate interval in Core 570-27. 